\title{
Validation of the ELORS Scale and Its Application to Detect Learning Deficiency in Childhood
}

\author{
Dulcinea Bandeira Soares Timbó1, Edgar Marçal2, Luan Victor Almeida Lima1, \\ Fernanda Remígio', Melissa Soares Medeiros ${ }^{1}$ \\ ${ }^{1}$ Unichristus University Center, Fortaleza, Brazil \\ ${ }^{2}$ Federal University of Ceará, Fortaleza, Brazil \\ Email: Dulcineabandeira@gmail.com, edgar@virtual.ufc.br, Luanvictor.al@gmail.com, Fernandaremigio@gmail.com, \\ melmedeiros@hotmail.com
}

How to cite this paper: Timbó, D. B. S., Marçal, E., Lima, L. V. A., Remígio, F., \& Medeiros, M. S. (2019). Validation of the ELORS Scale and Its Application to Detect Learning Deficiency in Childhood. Creative Education, 10, 2069-2081.

https://doi.org/10.4236/ce.2019.1010150

Received: June 4, 2019

Accepted: October 5, 2019

Published: October 8, 2019

Copyright $\odot 2019$ by author(s) and Scientific Research Publishing Inc. This work is licensed under the Creative Commons Attribution International License (CC BY 4.0).

http://creativecommons.org/licenses/by/4.0/

\begin{abstract}
Educational process in the appropriate period is paramount to define a better academic profile of young people in the future. The objective was to validate ELORS scale (Early Learning Observation and Rating Scale) to help educational process, emphasizing characteristics that can be early signals of learning deficiencies. Scale was applied to parents of 2 public schools and 2 private schools ( $\mathrm{N}=57$ students). Results of reliability using Cronbach's alpha were as follows: Perceptual and Motor (0.916), Self-management (0.896), Social and Emotional (0.893), Early Mathematics (0.956), Early Literacy (0.955), Receptive Language (0.943) and Expressive Language (0.948). When evaluated the differences between private and public schools, we found significant data in the Domain 2 in the behavior and mood consistency $(p=0.008)$; Domain 3 in functioning regardless of adult care $(p=0.006)$; Domain 4 in naming numbers ( $p=0.026)$, counting in the appropriate sequence $(p=0.035)$, counting objects with precision $(p=0.026)$, determining which of the two groups of objects has more or less objects $(p=0.017)$, determining which object comes next in a sequence (0.010), showing understanding of the basic time sequences ( $p=$ $0.041)$ and showing understanding of basic spatial orientation terms $(p=$ $0.010)$; Domain 5 in interest in writing their own name $(p=0.027)$, identifying words $(p=0.006)$, clapping on the number of syllables in a word ( $p=$ $0.033)$, and left to right and top to bottom reading $(p=0.006)$; Domain 6 in paying attention to speech with background noise $(p=0.046)$. Conclusion: The study identified children with the greatest difficulties in Early Literacy between 7 and 8 years old, Major difficulties in Mathematics, Early Literacy in public schools and higher difficulty in the domains of Self-management, Social and Emotional and Receptive Language in private schools.
\end{abstract}




\section{Keywords}

ELORS, Learning, Literacy, Education, Childhood

\section{Introduction}

Education is an important measure to determine how much a government values their population and culture. Education leads children to learn more than just basic academic knowledge; it is also about learning skills and cultural norms. Every nation in the world has its own form of education system. The major factors affecting education are resources and money. Poor countries that do not have them to support education systems are a social concern, different of rich countries. International differences in education systems are not only a financial issue. They are related to the value placed on education, time spent on it, and the distribution of education around the role country contributes a role in those differences (Knighton et al., 2010). Education is a right of the entire population in Brazil, and a lot has been built over the years to decrease the illiteracy rate in the country. The data supplied by IBGE (Brazilian Institute of Geography and Statistics) show, through the National Survey of Household Sampling (PNAD), a range of characteristics about the schooling achieved by the population and, primarily, students, which allows monitoring over the time the situations of illiteracy and schooling in the country, as well, as the level of education of the population. From 2007 to 2014, the decline in the illiteracy rate, the rise of the schooling rate of the age group from 6 to 14 years old, and the level of education rate remained. The instruction level increased from 2007 to 2014, and the group of people with, at least 11 schooling years, in the population aged 25 years old and over, went from $33.6 \%$ to $42.5 \%$. The female level of instruction remained higher than the male rate. In 2014, in the contingent of 25 years or more, the share with at least 11 years of study represented $40.3 \%$ for men and $44.5 \%$ for women. However, much still needs to be built to stimulate learning and adequate literacy; that is, it occurs at the correct time between 3 - 8 years of age (IBGE, 2017). Children's achievements in education will be influenced by support they receive at home, the quality of teachers, the teaching methods, the extent to which they are engaged in the educational process, the availability of resources, and flexibility. All these factors can be supported through government action. But it has to be understood that this is not just a government responsibility, it is also all members of the community, including parents (Lawrence-Lightfoot, 2004).

Parents' contribution can include: Providing an environment in the early years that ensures the child's preparedness to start school; Supporting and recognizing the right to education and the value of education for all their children; Ensuring that children are not overburdened with domestic and other work to the detriment of their schooling; Ensuring that children are prepared for school and able to arrive, ready and on time, when school is in session; Getting involved in the school and supporting its work; Showing encouragement and support for 
their child's work and, where possible, helping with homework; Advocating for children's right to education; Ensuring, to the extent possible, that their children are healthy and well nourished so they are able to learn; Ensuring that local traditions and customs do not prevent their children from going to school (Rogoff et al., 1996).

The ELORS (Early Learning Observation and Rating Scale) was created by researchers Mary Ruth Coleman, Tracey West and Margaret Gillis, from the National Center for Learning Disabilities in New York, USA. The ELORS scale was designed for children providing information across seven valuable developmental domains: Perceptual and Motor, Self-Management, Social and Emotional, Early Mathematics, Early Literacy, Receptive Language, and Expressive Language. There are 3 ELORS forms: Whole-Class, Teacher-Individual Child, and Parent-Individual Child. We chose to work with the Individual Parent-Individual Child Form, to foster a greater approximation of the parents or guardians to the school, motivating the teamwork to overcome the difficulties and needs and learning and development of the child (ELLORS Scale).

Learning disabilities (LD) are a heterogeneous group of disorders characterized by the unexpected failure of an individual to acquire, retrieve, and use information competently. They typically manifest as a failure to acquire reading, writing, or math skills at grade- and age-expected levels. But it can also be manifested as some signs and symptoms: difficulty understanding concepts of place value, and quantity, number lines, positive and negative value, carrying and borrowing; difficulty understanding and doing word problems; difficulty sequencing information or events; difficulty using steps involved in math operations; difficulty understanding fractions; is challenged making change and handling money; Displays difficulty recognizing patterns when adding, subtracting, multiplying, or dividing; difficulty putting language to math processes, difficulty understanding concepts related to time such as days, weeks, months, seasons, quarters; Exhibits difficulty organizing problems on the page, keeping numbers lined up, following through on long division problems (Hauerwas et al., 2013).

There are several instruments developed to screening through parent-reported impressions trying to detect early learning disabilities, as Minnesota Child Development Inventory (MCDI), which involves little professional time, and an individually administered psychological test, the McCarthy Scales of Children's Abilities (MSCA) (Kenny et al., 1987) and parent-completed Ages and Stages Questionnaires (ASQs) for detecting the developmental delay in preschool age children and clarification of possible associated risk factors (El Elella et al., 2017; Small et al., 2018). Reviewing some articles ELORS scale was selected as a practical and feasible tool to detect learning disabilities in Brazil (Tervo, 2005; Glascoe \& Dworkin, 1995; Burgess et al., 1984; Gillis et al., 2010).

The ELORS seems to be the appropriate tool to detect learning disabilities in the period of regular school literacy ( 3 - 8 years old), whilst allowing us to influence and stimulate family involvement in the education of the child. This scale has not yet been applied outside the United States and therefore would need to 
be validated and culturally adapted for its proper application in Brazil. The objective of this study is to validate and culturally adapt the ELORS to be used in Brazil to detect deficiencies of learning in literacy in adequate time. Moreover, we aim to detect the main areas of learning difficulty in Early Literacy and to promote and stimulate family involvement in the child's education in school (Coleman et al., 2011, Epstein et al., 2009).

\section{Methods}

We developed the study in two public and two private schools in the countryside of the state of Ceará (Ipu city), submitted to and approved by the Unichristus Ethics Committee. We reviewed the main guides on cultural adaptation and scale validation and decided to use the most cited methodology: the Guillemin F, Bombardier C, and Beaton D one. This methodology encompasses the following steps: translation by two independent individuals, back translation, assessment by the review committee to compare the original version to both translations, pretesting (which is a questionnaire applied to a sample population), and modification of the scores (Capretto, 2012; Dini et al., 2004; Guillemin, Bombardier, \& Beaton, 1993). We requested the use and adaptation of the ELORS to Doctor Tracey West of the National Center for Learning Disabilities by contacting the Center, which showed interest in applying it to another country.

The total number of questions on the scale is 77 . The child's individual assessment form is applied to the parents, thus enabling them to determine areas in which additional support or instruction is needed, and determine if additional assessments are necessary to understand the child's needs. If there is a 3 or 4 assessment for a domain, which indicates moderate to considerable concern, plans should be developed to provide the child with additional support or instruction in that area. This allows parents and teachers to act quickly and efficiently as a team. If there is an evaluation 4 for any domain, this indicates a great concern, which considers a need for further investigation. The additional evaluation may be general or for a specific domain, depending on the nature and severity of the concerns.

\section{Results and Discussion}

We applied the ELORS to a total of 57 students, 28 males and 29 females. Among the students evaluated, 22 studied in private school and 35 went to public school. Regarding age, the majority was 6 years old $(66.7 \%, \mathrm{~N}=38)$, followed by 7 year-olds $(26.3 \%, \mathrm{~N}=15)$, and a few 8 years of age $(5.3 \%, \mathrm{~N}=3)$ or 5 years old $(1.8 \%, \mathrm{~N}=1)$. The results obtained with the application of the ELORS with the students' parents can be evidenced in Figures 1-7, defined by the specific domains of the evaluation. The reliability assessment of the scale responses was performed by determining Cronbach's alpha for each domain (Table 1) (Malhotra, 2008). 
D. B. S. Timbó et al.

Table 1. Cronbach's alpha calculation reliability assessment.

\begin{tabular}{cccc}
\hline \multirow{2}{*}{ Learning Domain } & Intraclass Correlation & \multicolumn{2}{c}{ Confidence Interval 95\% } \\
\cline { 3 - 4 } & & Inferior Limit & Upper Limit \\
\hline Perceptual and Motor & 0.916 & 0.880 & 0.945 \\
Self-Management & 0.896 & 0.851 & 0.932 \\
Social and Emotional & 0.893 & 0.846 & 0.930 \\
Early Mathematics & 0.970 & 0.956 & 0.980 \\
Early Literacy & 0.955 & 0.935 & 0.970 \\
Receptive Language & 0.943 & 0.917 & 0.963 \\
Expressive Language & 0.948 & 0.925 & 0.966 \\
\hline
\end{tabular}

${ }^{*}$ We calculate this estimate considering that the interaction effect is absent because it cannot be estimated otherwise.

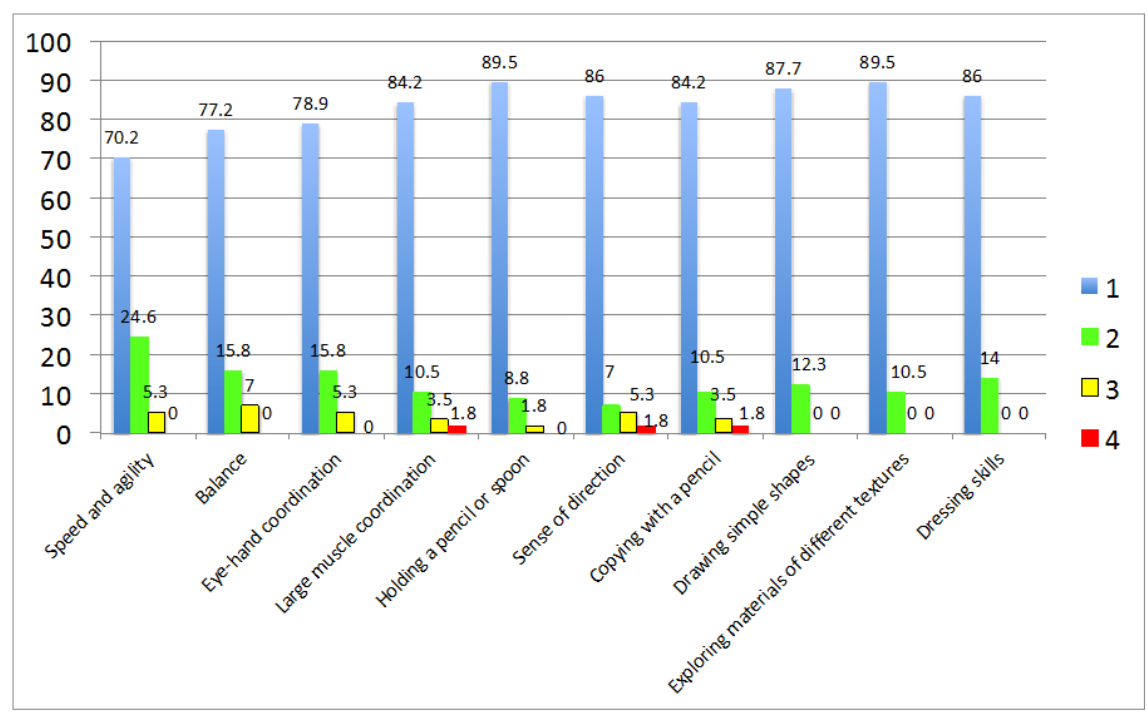

Figure 1. ELORS evaluation of learning Domain 1: perceptual and motor.

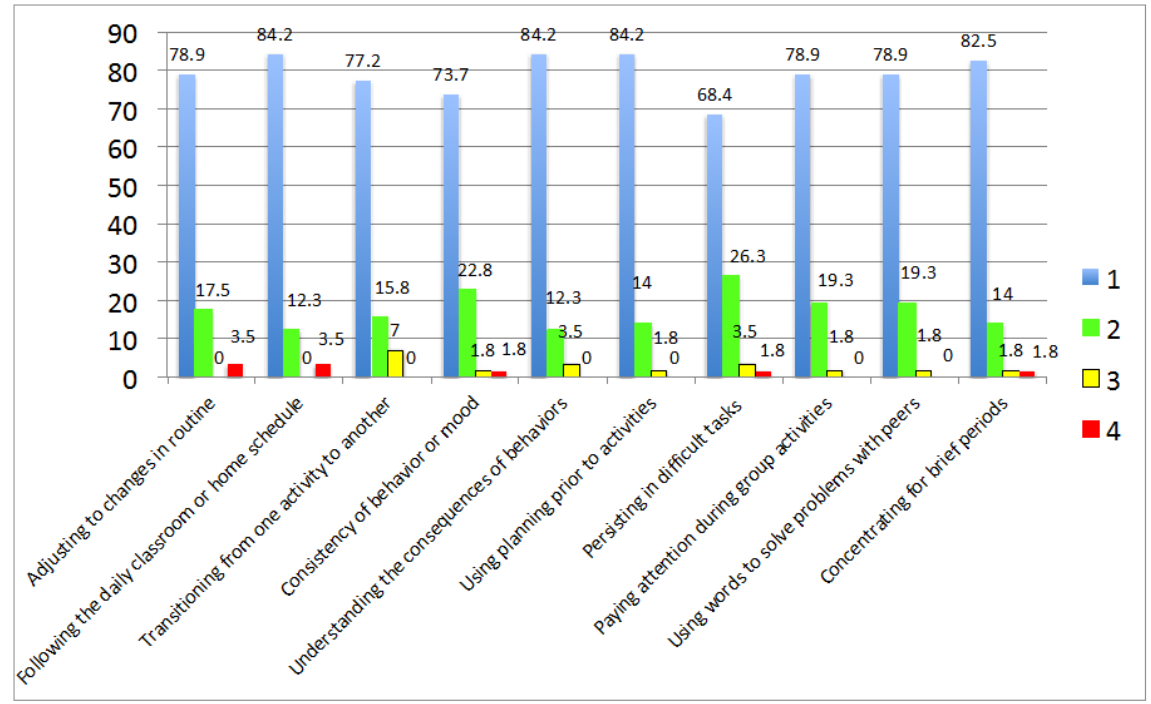

Figure 2. ELORS evaluation of learning Domain 2: self-management. 


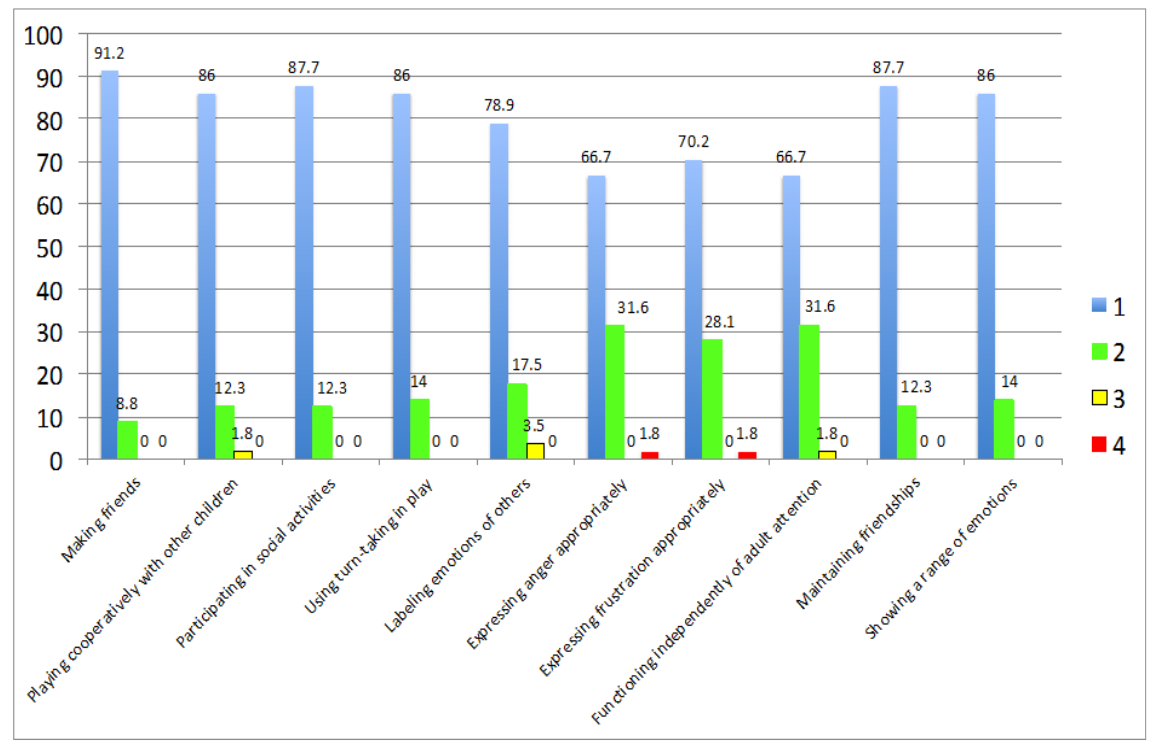

Figure 3. ELORS evaluation of learning Domain 3: social and emotional.

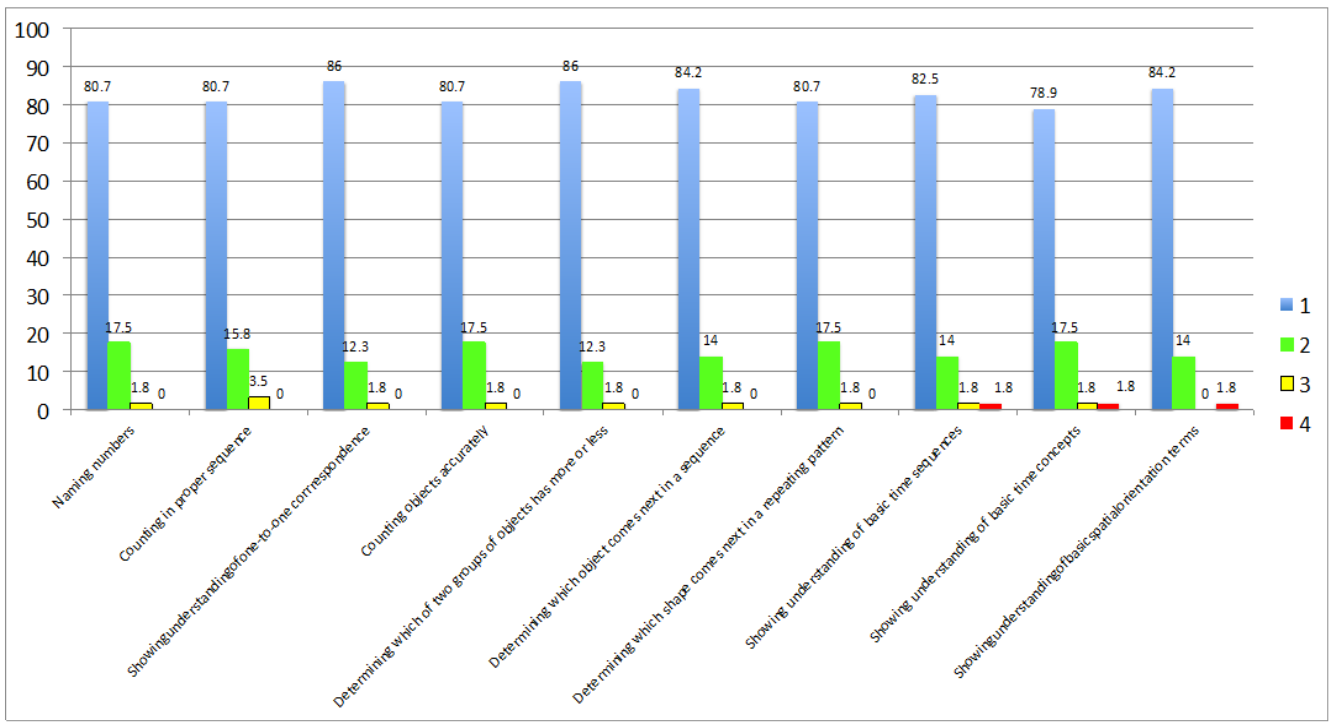

Figure 4. ELORS evaluation of learning Domain 4: early mathematics.

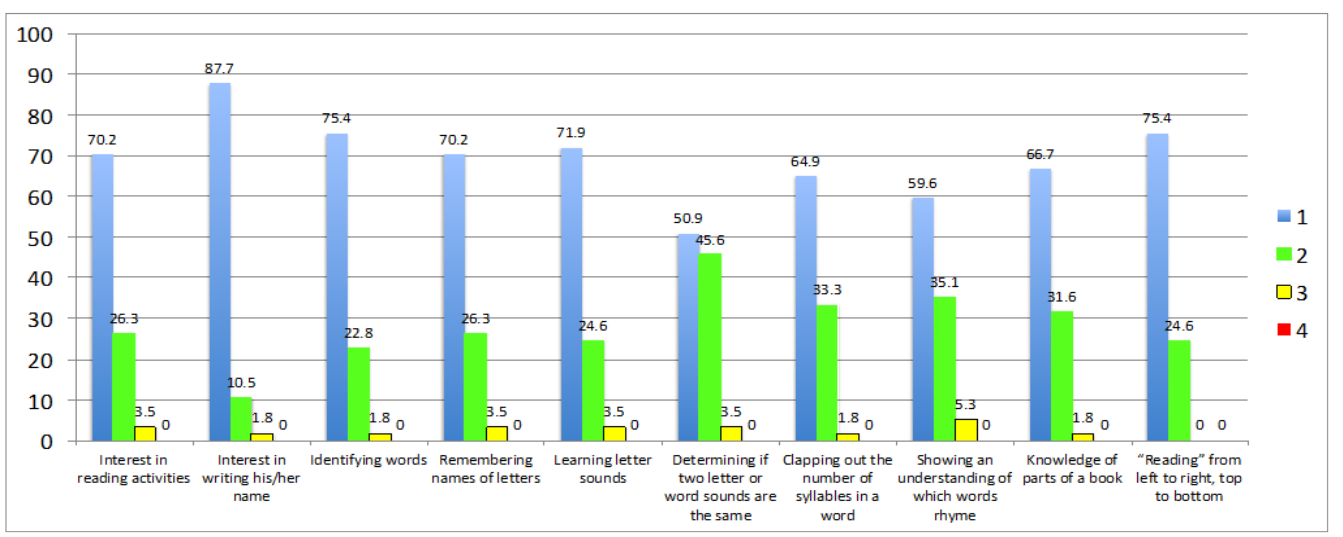

Figure 5. ELORS evaluation of learning Domain 5: early literacy. 


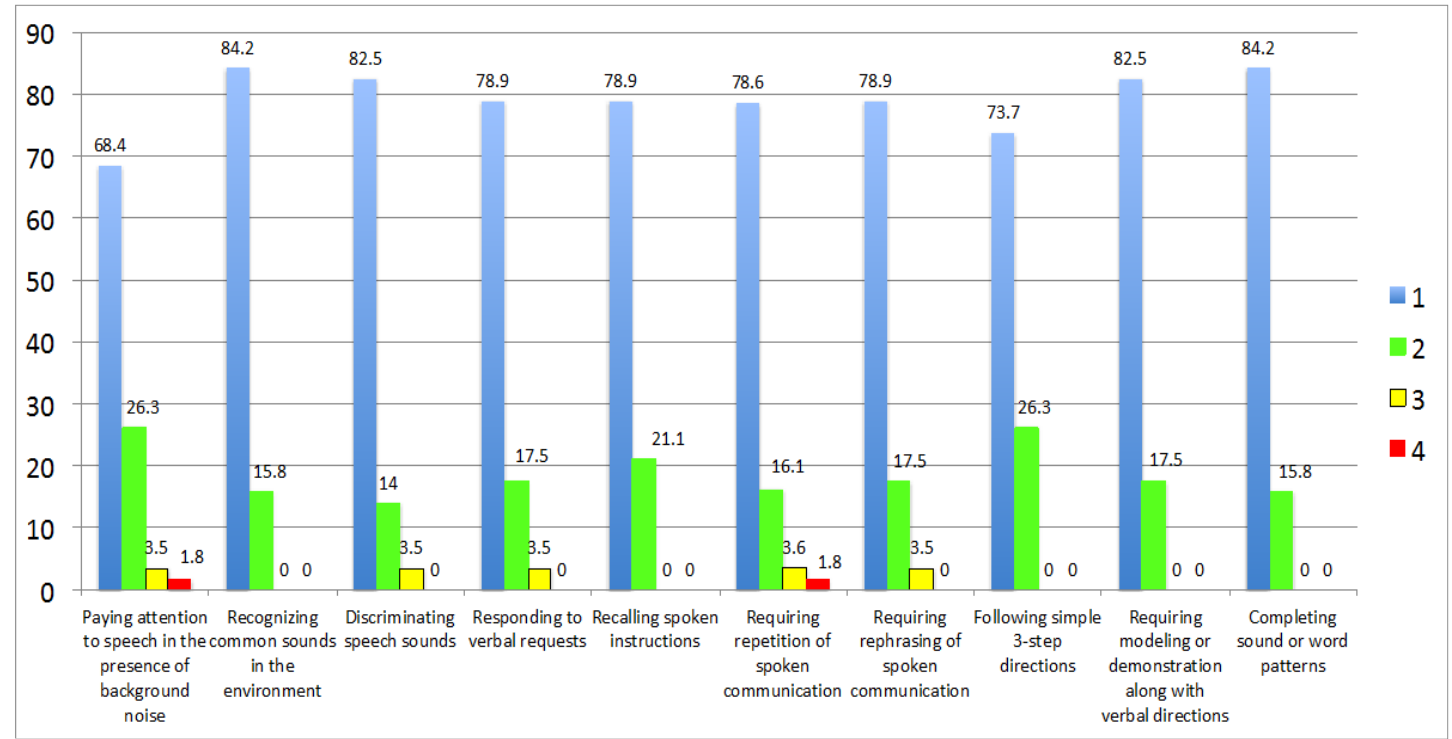

Figure 6. ELORS evaluation of learning Domain 6: receptive language.

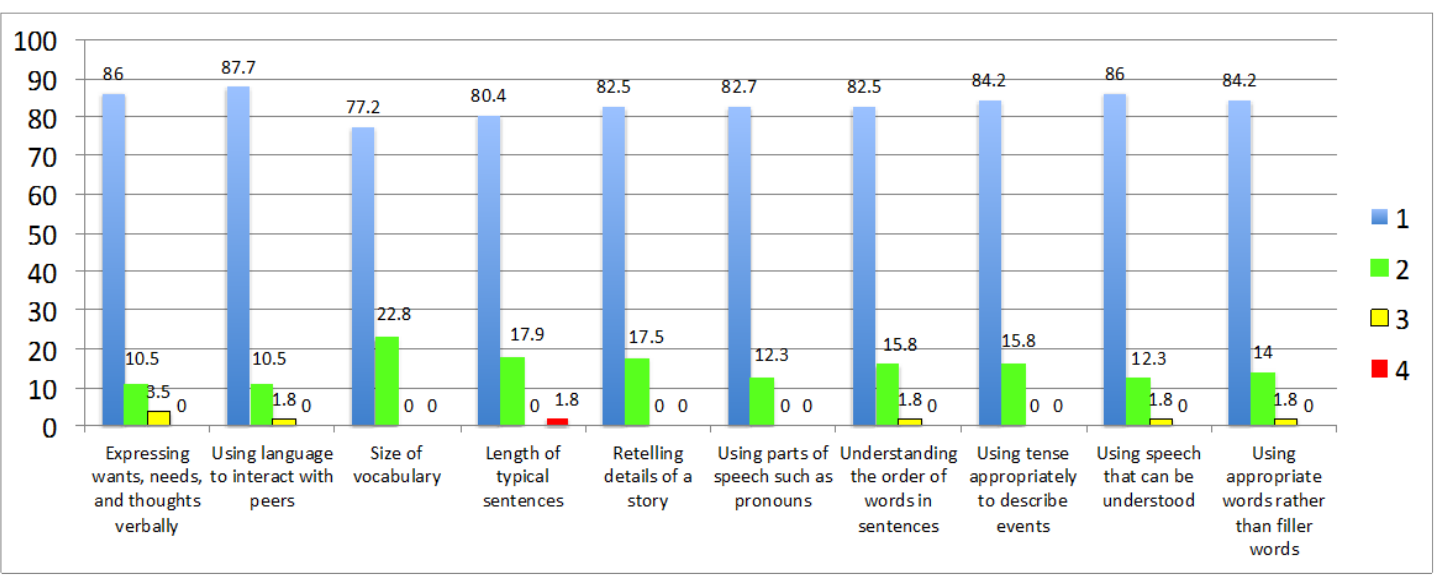

Figure 7. ELORS evaluation of learning Domain 7: expressive language.

Non-parametric analysis proved that the distribution is the same between the age categories for the domains $1(p=0.752), 2(p=0.662), 3(p=0.998), 4(p=$ $0.114), 5(p=0.243), 6(p=0.352)$ and $7(p=0.432)$. The nonparametric tests to evaluate the null hypothesis concerning questions of the areas, with results using Kruskal-Wallis test for independent samples and the age-related difference between public and private schools, displayed statistically significant results only for: Assessment in age differences only in the Domain 5 (Early Literacy) for the items: Remembering letter names $(p=0.17)$ and learning letter sounds $(p=0.016)$, which concerns more in older children ( 7 and 8 years), highlighting difficulties in literacy at the appropriate period by the parents (Table 2). Non-parametric analysis proved that the distribution is the same between the categories of schools regarding domains $4(p=0.530), 5(p=0.632)$ and $7(p=0.223)$. However, the distribution was not the same for the domains $1(p=0.017), 2(p=0.022), 3(p=$ $0.009)$ and $6(p=0.017)$. 
Table 2. Assessment of differences in Domain 5 of early literacy in relation to age.

\begin{tabular}{|c|c|c|c|c|c|c|c|c|c|c|}
\hline \multirow{2}{*}{\multicolumn{2}{|c|}{ Domain 5. Early Literacy }} & \multicolumn{2}{|c|}{5 years old } & \multicolumn{2}{|c|}{6 years old } & \multicolumn{2}{|c|}{7 years old } & \multicolumn{2}{|c|}{8 years old } & \multirow{2}{*}{$p$} \\
\hline & & $\mathrm{N}$ & $\%$ & $\mathrm{~N}$ & $\%$ & $\mathrm{~N}$ & $\%$ & $\mathrm{~N}$ & $\%$ & \\
\hline \multirow{3}{*}{$\begin{array}{c}\text { Remembering letter } \\
\text { names }\end{array}$} & 1 & 1 & $100 \%$ & 26 & $68.4 \%$ & 13 & $86.7 \%$ & 0 & $0 \%$ & \multirow{3}{*}{0.009} \\
\hline & 2 & 0 & $0 \%$ & 12 & $31.6 \%$ & 1 & $6.7 \%$ & 2 & $66.7 \%$ & \\
\hline & 3 & 0 & $0 \%$ & 0 & $0 \%$ & 1 & $6.7 \%$ & 1 & $33.3 \%$ & \\
\hline \multirow{4}{*}{ Learning letter sounds } & 1 & 1 & $100 \%$ & 27 & $71.1 \%$ & 13 & $86.7 \%$ & 0 & $0 \%$ & \multirow{4}{*}{0.01} \\
\hline & 2 & 0 & $0 \%$ & 11 & $28.9 \%$ & 1 & $6.7 \%$ & 2 & $66.7 \%$ & \\
\hline & 3 & 0 & $0 \%$ & 0 & $0 \%$ & 1 & $6.7 \%$ & 1 & $33.3 \%$ & \\
\hline & 2 & 0 & $0 \%$ & 10 & $26.3 \%$ & 2 & $13.3 \%$ & 2 & $66.7 \%$ & \\
\hline
\end{tabular}

When we evaluated the differences between private and public schools we found significant data in Domain 2 (self-management) in the behavior and mood consistency item $(p=0.008)$, in which $9 \%$ of private school parents reported grade 3 or 4 concern, and $85.7 \%$ of parents in public schools reported no concerns compared to $54.5 \%$ in the private school. We also found evidence in Domain 3 (Social and Emotional) in the item functioning regardless of adult care $(p=0.006)$, in which $4.5 \%$ of the parents in private school showed concern degree 3. Regarding Domain 4 (Early Mathematics) there was difference ( $p=$ $0.026)$ in the distribution of public and private schools in relation to counting in the appropriate sequence $(p=0.035)$, counting objects accurately $(p=0.026)$, determining which of two groups of objects has more or less $(p=0.017)$, determining which object comes next in a sequence $(0.010)$, showing understanding of the basic time sequences $(p=0.041)$ and showing understanding of basic spatial orientation terms $(p=0.010)$ (Table 3$)$. There was evidence of greater difficulties for public schools.

In the Domain 6 (Receptive Language) there was a difference in the distribution between private and public schools in relation to the item paying attention to speech in the presence of background noise $(p=0.046)$, with higher concern in the private school being grade 3 in $9.1 \%$ and grade 4 in $4.5 \%$. Private school children seem to be more likely to get distracted by outside factors. In Domain 7 (Expressive Language) there was a difference in the distribution of items expressing desire, needs and thoughts verbally $(p=0.017)$, using language to interact with peers $(p=0.027)$ and using parts of speech such as pronouns $(p=$ 0.026 ) (Table 4). There is increased concern in this area for the parents of public school students.

Referring to Domain 5 (Early Literacy) there was a difference in the distribution between private and public schools in relation to items showing interest in writing their own name $(p=0.027)$, identifying words $(p=0.006)$, applauding the number of syllables in a word ( $p=0.033)$, and reading from left to right and from top to bottom $(p=0.006)$ (Table 5$)$. There is also a more significant concern in public schools. 
Table 3. Evaluation of Domain 4 (Early Mathematics) in relation to school.

\begin{tabular}{|c|c|c|c|c|c|c|}
\hline \multirow{3}{*}{ Domain 4. Early Mathematics } & & \multicolumn{5}{|c|}{ School } \\
\hline & & \multicolumn{2}{|c|}{ Private } & \multicolumn{2}{|c|}{ Public } & \multirow{2}{*}{$P$} \\
\hline & & $\mathbf{N}$ & $\%$ & $\mathbf{N}$ & $\%$ & \\
\hline \multirow{4}{*}{ Naming numbers } & 1 & 21 & $95.5 \%$ & 25 & $71.4 \%$ & \multirow{4}{*}{0.080} \\
\hline & 2 & 1 & $4.5 \%$ & 9 & $25.7 \%$ & \\
\hline & 3 & 0 & $0 \%$ & 1 & $2.9 \%$ & \\
\hline & 1 & 21 & $95.5 \%$ & 25 & $71.4 \%$ & \\
\hline \multirow[t]{3}{*}{ Counting in the appropriate sequence } & 2 & 0 & $0 \%$ & 9 & $25.7 \%$ & \multirow[t]{3}{*}{0.035} \\
\hline & 3 & 1 & $4.5 \%$ & 1 & $2.9 \%$ & \\
\hline & 1 & 21 & $95.5 \%$ & 25 & $71.4 \%$ & \\
\hline \multirow[t]{3}{*}{ Counting objects with precision } & 2 & 1 & $4.5 \%$ & 9 & $25.7 \%$ & \multirow[t]{2}{*}{0.080} \\
\hline & 3 & 0 & $0 \%$ & 1 & $2.9 \%$ & \\
\hline & 1 & 22 & $100 \%$ & 27 & $77.1 \%$ & \multirow{3}{*}{0.054} \\
\hline \multirow[t]{3}{*}{$\begin{array}{l}\text { Determining which of } \\
\text { the groups has more or less }\end{array}$} & 2 & 0 & $0 \%$ & 7 & $20 \%$ & \\
\hline & 3 & 0 & $0 \%$ & 1 & $2.9 \%$ & \\
\hline & 1 & 22 & $100 \%$ & 26 & $74.3 \%$ & \multirow{3}{*}{0.035} \\
\hline \multirow[t]{3}{*}{$\begin{array}{l}\text { Determining which object } \\
\text { comes next in a sequence }\end{array}$} & 2 & 0 & $0 \%$ & 8 & $22.9 \%$ & \\
\hline & 3 & 0 & $0 \%$ & 1 & $2.9 \%$ & \\
\hline & 1 & 21 & $95.5 \%$ & 26 & $74.3 \%$ & \multirow{4}{*}{0.232} \\
\hline \multirow{3}{*}{$\begin{array}{l}\text { Showing understanding of } \\
\text { basic time sequences }\end{array}$} & 2 & 1 & $4.5 \%$ & 7 & $20 \%$ & \\
\hline & 3 & 0 & $0 \%$ & 1 & $2.9 \%$ & \\
\hline & 4 & 0 & $0 \%$ & 1 & $2.9 \%$ & \\
\hline \multirow{3}{*}{$\begin{array}{l}\text { Showing understanding of } \\
\text { basic spatial orientation terms }\end{array}$} & 1 & 22 & $100 \%$ & 26 & $74.3 \%$ & \multirow{3}{*}{0.035} \\
\hline & 2 & 0 & $0 \%$ & 8 & $22.9 \%$ & \\
\hline & 4 & 0 & $0 \%$ & 1 & $2.9 \%$ & \\
\hline
\end{tabular}

Table 4. Evaluation of Domain 7 (Expressive Language) regarding private and public schools.

\begin{tabular}{|c|c|c|c|c|c|c|}
\hline \multirow{3}{*}{ Domain 7. Expressive Language } & & \multicolumn{5}{|c|}{ School } \\
\hline & & \multicolumn{2}{|c|}{ Private } & \multicolumn{2}{|c|}{ Public } & \multirow{2}{*}{$P$} \\
\hline & & $\mathbf{N}$ & $\%$ & $\mathbf{N}$ & $\%$ & \\
\hline \multirow{3}{*}{ Expressing desire, needs and thoughts verbally } & 1 & 22 & $100 \%$ & 27 & $77.1 \%$ & \multirow{3}{*}{0.054} \\
\hline & 2 & 0 & $0 \%$ & 6 & $17.1 \%$ & \\
\hline & 3 & 0 & $0 \%$ & 2 & $5.7 \%$ & \\
\hline \multirow{3}{*}{ Using language to interact with peers } & 1 & 22 & $100 \%$ & 28 & $80 \%$ & \multirow{3}{*}{0.081} \\
\hline & 2 & 0 & $0 \%$ & 6 & $17.1 \%$ & \\
\hline & 3 & 0 & $0 \%$ & 1 & $2.9 \%$ & \\
\hline \multirow{2}{*}{ Using parts of the speech, such as pronouns } & 1 & 22 & $100 \%$ & 28 & $80 \%$ & \multirow{2}{*}{0.025} \\
\hline & 2 & 0 & $0 \%$ & 7 & $20 \%$ & \\
\hline
\end{tabular}


Table 5. Evaluation of Domain 5 (Early Literacy) in relation to school.

\begin{tabular}{|c|c|c|c|c|c|c|}
\hline \multirow{3}{*}{ Domain 5. Early Literacy. } & & \multicolumn{5}{|c|}{ School } \\
\hline & & \multicolumn{2}{|c|}{ Private } & \multicolumn{2}{|c|}{ Public } & \multirow{2}{*}{$P$} \\
\hline & & $\mathrm{N}$ & $\%$ & $\mathbf{N}$ & $\%$ & \\
\hline \multirow{4}{*}{ Showing interest in writing their names } & 1 & 22 & $100 \%$ & 28 & $80 \%$ & \multirow{4}{*}{0.081} \\
\hline & 2 & 0 & $0 \%$ & 6 & $17.1 \%$ & \\
\hline & 3 & 0 & $0 \%$ & 1 & $2.9 \%$ & \\
\hline & 1 & 21 & $95.5 \%$ & 22 & $62.9 \%$ & \\
\hline \multirow[t]{3}{*}{ Identifying words } & 2 & 1 & $4.5 \%$ & 12 & $34.3 \%$ & \multirow[t]{2}{*}{0.021} \\
\hline & 3 & 0 & $0 \%$ & 1 & $2.9 \%$ & \\
\hline & 1 & 18 & $81.8 \%$ & 19 & $54.3 \%$ & \multirow{3}{*}{0.097} \\
\hline \multirow[t]{2}{*}{ Clapping to the number of syllables in a word } & 2 & 4 & $18.2 \%$ & 15 & $42.9 \%$ & \\
\hline & 3 & 0 & $0 \%$ & 1 & $2.9 \%$ & \\
\hline \multirow{2}{*}{ Reading from left to right, from top to bottom } & 1 & 21 & $95.5 \%$ & 22 & $62.9 \%$ & \multirow{2}{*}{0.005} \\
\hline & 2 & 1 & $4.5 \%$ & 13 & $37.1 \%$ & \\
\hline
\end{tabular}

Research has accumulated over the last few decades on the importance of high-quality pre-school education to prepare children for their journey through the entire school period (Reynolds, 2000; Reynolds et al., 2001). At the same time, for more than 30 years (Kagan, 1984; Epstein, 1995; Becker \& Epstein, 1982), research on family and community involvement has shown that children are most successful in school when their parents and teachers communicate well and work together effectively (Epstein, 2011; Henderson et al., 2007).

Studies indicate that at any undergraduate level, including pre-kindergarten, challenging curricula, important learning goals, effective assessments, feedback to students, and parental involvement are important to increase student achievement, attendance, behavior, and other important school outcomes (Bryk et al., 2011; Marzano, 2003; Sheldon, 2003). Although studies have varied in sample size, duration, data collected, and methods of analysis, the literary structure points in one direction: school benefits when parents and teachers work together as partners in education.

Despite all these positive results, the applicability at home and in schools is rare and often occurs spontaneously. Some media also help to disseminate ways to connect parents with their children's learning (Capretto, 2012; Feiler, 2012; Larsen \& Rodgers, 2003). In the United States, the percentage of children whose family members read to them between the ages of $3-5$ years was $78 \%$ in 1993 and 86\% in 2005 (Learning Disabilities Association of America). Although the poverty level of the family has differed in this percentage ( $90 \%$ of children in families above the poverty line compared to $78 \%$ of children in families below the poverty line), there is no difference in storytelling by parents, working with letters, words or numbers, or teaching music to their children. 


\section{Conclusion}

Through the application of the ELORS with different ages, we were able to identify the students with the most considerable difficulties in initial literacy between 7 and 8 years old. Regarding the comparison between public and private schools, we obtained a different profile of difficulties, pointing to more significant difficulties in Early Mathematics and Early Literacy in public schools, requiring a greater encouragement of parents and community for the educational formation in these domains. Besides, greater difficulty in the domains of self-management, social-emotional, and receptive language in private schools denoting a greater dependence on children and dispersion by external factors during learning activities.

Albeit there is still a lot to learn about how to connect with and support the efforts of caregivers to promote child learning, what we have already learned from the research so far may guide us into the next level. We believe that achieving a higher rate of early literacy in Brazil is possible with greater family involvement, allowing early detection of learning disabilities and referrals to specialists who will reduce future damage to these children, both academic and psychological. More studies need to specifically identify which family involvement practices and which school extension strategies are most effective for all students and families, especially for subgroups of family and students.

Early diagnosis not only improves the child's ability to reach their academic potential, but also prevents the development of low self-esteem and behavior problems that further interfere with their ability to learn. Without early diagnosis, the potential to develop the skills they need to have a normal, successful life as an adult can be greatly reduced. The purpose of the Early Learning Observation Rating Scale (ELORS) is to help teachers and parents gather and share information about young children with specific attention to characteristics that might be early signs of learning disabilities. The ELORS allows teachers and parents to recognize if the child would benefit from additional support. Family involvement in education is essential for young children's literacy and math skills. Hence, when parents are more engaged, children tend to improve academically and socially (Larsen \& Rodgers, 2003; Marzano, 2003; Sheldon, 2003; Sheldon \& Epstein, 2005). The ELORS facilitates problem solving because it converges conversation in shared observations of actual behaviors in naturalistic settings. To be most useful, parents must take an active role in the problem-solving process by contributing information about their children. The ELORS can help to organize and focus the parent's concerns during these conversations. When areas of concern have been identified, using the ELORS, these can be addressed. To provide appropriate support, recognizing that the child is suffering is essential. This is where the ELORS can become the bridge between teachers and parents.

\section{Conflicts of Interest}

The authors declare no conflicts of interest regarding the publication of this paper. 


\section{References}

Becker, H. J., \& Epstein, J. L. (1982). Parent Involvement: A Study of Teacher Practices. Elementary School Journal, 83, 85-102. https://doi.org/10.1086/461297

Bryk, A. S., Sebring, P. B., Allensworth, E., Luppescu, S., \& Easton, J. Q. (2011). Organizing Schools for Improvement: Lessons from Chicago. Chicago: University of Chicago Press.

Burgess, D. B., Asher, K. N., Doucet, H. J. 3rd et al. (1984). Parent Report as a Means of Administering the Prescreening Developmental Questionnaire: An Evaluation Study. Journal of Developmental \& Behavioral Pediatrics, 5, 195. https://doi.org/10.1097/00004703-198408000-00007

Capretto, L. (2012). 38 Easy Ways to Get Involved in the Classroom. http://www.oprah.com/relationships/38-Ways-for-Parents-to-Get-Involved-in-the-Cla ssroom-Back-to-School

Coleman, M. R., Gillis, M., \& West, T. (2011). The Early Learning Observation \& Rating Scale (ELORS): Honoring Parent and Teacher Concerns. Perspectives on Language and Literacy, 37, 35-37.

Dini, G. M., Quaresma, M. R., \& Ferreir, L. M. (2004). Translation into Portugues, Cultural Adaptation and Validation of the Rosenberg Self-Esteem Scale. Brazilian Journal of Plastic Surgery, 19, 41-52.

El Elella, S. A., Tawfik, M. A., El Fotoh, W. M. A., \& Barseem, N. (2017). Screening for Developmental Delay in Preschool-Aged Children Using Parent-Completed Ages and Stages Questionnaires: Additional Insights into Child Development. Postgraduate Medical Journal, 93, 597-602. https://doi.org/10.1136/postgradmedj-2016-134694

ELLORS Scale. http://www.getreadytoread.org/screening-tools/early-learning-observation-rating-scale

Epstein, J. L. (1995) School/Family/Community Partnerships: Caring for the Children We Share. Phi Delta Kappan, 76, 701-712.

Epstein, J. L. (2001). School, Family, and Community Partnerships: Preparing Educators and Improving Schools (p. 85). Reston, VA: National Association of Secondary School Principals. https://doi.org/10.1177/019263650108562710

Epstein, J. L., Sanders, M. G., Sheldon, S., Simon, B. S., Salinas, K. C., Jansorn, N. R., \& Van Voorhis, F. L. V. (2009). School, Family, and Community Partnerships: Your Handbook for Action. Newbury Park, CA: Corwin Press.

Feiler, B. (2012). It's OK to Skip That Bake Sale. New York Times. http://www.nytimes.com/2012/09/02/fashion/finding-the-right-amount-of-parental-in volvement-in-school.html?ref=parenting\&_r $=0$

Gillis, M., West, T., \& Coleman, M. R. (2010). Early Learning Observation \& Rating Scale: Teacher's Guide. New York: National Center for Learning Disabilities.

Glascoe, F. P., \& Dworkin, P. H. (1995). The Role of Parents in the Detection of Developmental and Behavioral Problems. Pediatrics, 95, 829.

Guillemin, F., Bombardier, C., \& Beaton, D. (1993). Cross-Cultural Adaptation of Health-Related Quality of Life Measures: Literature Review and Proposed Guidelines. Journal of Clinical Epidemiology, 46, 1417-1432. https://doi.org/10.1016/0895-4356(93)90142-N

Hauerwas, L. B., Brown, R., \& Scott, A. N. (2013). Specific Learning Disability and Response to Intervention: State-Level Guidance. Except Child, 80, 101. https://doi.org/10.1177/001440291308000105 
Henderson, A. T., Mapp, K. L., Johnson, V. R., \& Davies, D. (2007). Beyond the Bake Sale: The Essential Guide to Family-School Partnerships. New York, NY: The New Press.

IBGE Site (2017). https://loja.ibge.gov.br/pnad-continua-educac-o-2017.html

Kagan, S. L. (1984). Parent Involvement Research: A Field in Search of Itself. Boston, MA: Institute for Responsive Education.

Kenny, T. J., Hebel, J. R., Sexton, M. J., \& Fox, N. L. (1987). Developmental Screening Using Parent Report. Journal of Developmental \& Behavioral Pediatrics, $8,8$. https://doi.org/10.1097/00004703-198702000-00003

Knighton, T., Brochu, P., \& Gluszynski, T. (2010). Measuring Up: Canadian Results of the OECD PISA Study. Statistics Canada Catalogue No. 81-590-X.

Larsen, E. F., \& Rodgers, L. (2003). New Math Homework Help. http://www.parenting.com/mathematics-reasoning-homework-help

Lawrence-Lightfoot, S. (2004). Building Bridges from School to Home. Instructor, 114, 24-28. http://www.parenting.com/mathematics-reasoning-homework-help

Learning Disabilities Association of America (n.d.). Dyscalculia. http://ldaamerica.org/types-of-learning-disabilities/dyscalculia

Malhotra, N. K. (2008). Pesquisa de Marketing: Uma Orientação Aplicada. Porto Alegre: Bookman.

Marzano, R. J. (2003). What Works in Schools: Translating Research into Action. Alexandria: Association for Supervision and Curriculum Development.

Reynolds, A. J. (2000). Success in Early Intervention: The Chicago Child-Parent Centers. Lincoln: University of Nebraska Press.

Reynolds, A. J., Temple, J. A., Robertson, D. L., \& Mann, E. A. (2001). Long-Term Effects of an Early Childhood Intervention on Educational Achievement and Juvenile Arrest: A 15-Year Follow-Up of Low-Income Children in Public Schools. Journal of the American Medical Association, 285, 2339-2346.

https://doi.org/10.1001/jama.285.18.2339

Rogoff, B., Matusov, E., \& White, C. (1996). Models of Teaching and Learning: Participation in a Community of Learners. In D. Olson, \& N. Torrance (Eds.), Handbook of Education and Human Development: New Models of Learning, Teaching, and Schooling (pp. 388-414). London: Blackwell.

Sheldon, S. B. (2003). Linking School-Family-Community Partnerships in Urban Elementary Schools to Student Achievement on State Tests. Urban Review, 35, 149-166. https://doi.org/10.1023/A:1023713829693

Sheldon, S. B., \& Epstein, J. L. (2005). Involvement Counts: Family and Community Partnerships and Mathematics Achievement. Journal of Educational Research, 98, 196-207. https://doi.org/10.3200/JOER.98.4.196-207

Small, J. S., Hix-Small, H., Vargas-Baron, E. P., \& Marks, K. (2018). Comparative Use of the Ages and Stages Questionnaires in Low- and Middle-Income Countries. Developmental Medicine \& Child Neurology, 61, 431-443. https://doi.org/10.1111/dmcn.13938

Tervo, R. C. (2005). Parent's Reports Predict Their Child's Developmental Problems. Clinical Pediatrics, 44, 601. https://doi.org/10.1177/000992280504400708 